\title{
WACANA PENGUATAN PENDIDIKAN KARAKTER DALAM BUKU TEKS SEJARAH INDONESIA
}

\author{
Rica Filasari ${ }^{1}$, Lutfiah Ayundasari ${ }^{2}$ \\ Universitas Negeri Malang \\ rfilasari@gmail.com, lutfiah.fis@um.ac.id
}

\begin{abstract}
This study aims to describe the PPK discourse in the Indonesian History textbook 2013 Curriculum of Senior High Schools (SMA). The research approach used is a qualitative type of critical discourse analysis model Roger Fowler et al. The main data source is in the revised edition of the High School Indonesia History textbook 2013. The research data was collected by means of documentation. While the data are analyzed with two levels, namely the micro level which takes into account the composition of words and sentences in the text and the macro level that links with the history books and the value of character education. Data checking is carried out holistically, historical situated, and theoretically by observing PPK in Indonesian History textbooks. The results of this study present nationalism as the theme of character values that most often appears in Indonesian History textbooks, followed by values of independence, religious, integrity, and mutual cooperation. The discourse of nationalism is very dominant in almost every textbook, especially narratives about the spirit of nationalism in the process of nation and state formation.
\end{abstract}

Keywords: History textbooks, Strengthening Character Education (PPK), discourse

\begin{abstract}
Abstrak: Penelitian ini bertujuan untuk mendeskripsikan wacana PPK dalam Buku Ajar Sejarah Indonesia Kurikulum 2013 Sekolah Menengah Atas (SMA). Pendekatan penelitian yang digunakan adalah model analisis wacana kritis tipe kualitatif Roger Fowler et al. Sumber data utama adalah Buku Ajar Sejarah Indonesia Sekolah Menengah Atas edisi revisi 2013. Pengumpulan data dilakukan dengan cara dokumentasi. Sedangkan data dianalisis dengan dua level, yaitu level mikro yang memperhitungkan komposisi kata dan kalimat dalam teks dan level makro yang terkait dengan buku sejarah dan nilai pendidikan karakter. Pengecekan data dilakukan secara holistik, letak historis, dan teoritis dengan memperhatikan PPK dalam buku teks Sejarah Indonesia. Hasil penelitian ini menghadirkan nasionalisme sebagai tema nilai-nilai karakter yang paling banyak muncul dalam buku teks sejarah Indonesia, diikuti oleh nilai-nilai kemandirian, agama, integritas, dan gotong royong. Wacana nasionalisme sangat dominan hampir di setiap buku teks, terutama penuturan tentang jiwa nasionalisme dalam proses pembentukan bangsa dan negara.
\end{abstract}

Kata kunci: Buku Ajar Sejarah, Penguatan Pendidikan Karakter (PPK), diskursus. 


\section{PENDAHULUAN}

Pembentukan karakter sejak dini adalah proses yang sangat penting dalam kegiatan pembelajaran. Karakter adalah akhlak atau kepribadian yang digunakan oleh seseorang sebagai landasan untuk menentukan sikap, cara pandang, pola pikir, dan tindakan yang akan dilakukan. Sebagai aspek kepribadian, karakter adalah cerminan dari kepribadian secara utuh dari seseorang yang terbentuk dari pembiasaan di lingkungan pendidikan (Mardikarini \& Suwarjo, 2016:262; Mulyasa, 2011:5). Berkaitan dengan hal tersebut pemerintah berusaha mewujudkannya dengan mencanangkan Penguatan Pendidikan Karakter di lingkungan persekolahan.

Terdapat lima nilai karakter utama dalam PPK yang ingin ditekankan oleh pemerintah yaitu nasionalisme, kemandirian, religius, integritas, dan gotong royong. PPK dicanangkan oleh pemerintah melalui sistem pendidikan nasional agar masyarakat baik di lingkungan pendidikan maupun masyarakat umum dapat mengetahui, memahami, dan menerapkannya dalam kehidupan sehari-hari (Kemdikbud, 2019).

Berdasarkan hal tersebut, seharusnya penerapan PPK di sekolah perlu mendapatkan perhatian serius khususnya oleh pendidik agar peserta didik dapat mengembangkan dan menerapkan karakter di kehidupan sehari-hari dengan baik. Marzuki (2012:41) memandang penting agar pendidikan karakter diadaptasi dan diimplementasikan dalam buku ajar yang dimanfaatkan oleh guru dan siswa pada proses kegiatan belajar mengajar, termasuk buku teks pelajaran sejarah Indonesia. 
Ada berbagai cara dalam penyampaian PPK, salah satunya bisa melalui buku teks. Menurut Mardikarini \& Suwarjo (2016:263) buku teks merupakan salah satu alat untuk mencapai kompetensi yang telah ditetapkan dengan cara diberikan secara langsung kepada peserta didik agar mereka dapat menemukan sendiri pengetahuan secara mandiri. Meskipun dalam kenyataannya, ada keraguaan sejauh mana PPK telah diintegrasikan dalam penulisan buku teks mengingat buku teks Sejarah Indonesia lahir terlebih dahulu daripada PPK.

Tarigan (2009:14) menyatakan bahwa dunia kini adalah dunia buku atau dengan kata lain dunia kini adalah dunia baca. Sampai saat ini buku teks merupakan salah satu sarana yang paling memungkinkan untuk memberikan pengaruh besar dalam kesuksesan kegiatan pembelajaran, tidak terkecuali dalam proses pembelajaran sejarah. Dalam pembelajaran sejarah buku adalah perwujudan peristiwa masa lalu dalam bentuk teks yang dapat membantu siswa belajar secara kronologis. Oleh karena itu, untuk membentuk kesadaran nilai-nilai kebangsaan maka diperlukan integrasi nilai-nilai PPK dalam penulisan buku teks Sejarah Indonesia.

Buku teks mata pelajaran Sejarah Indonesia seyogyanya merupakan sarana yang penting dalam penanaman nilai karakter. Posisi buku teks dalam pembelajaran sangat penting, seperti yang dikatakan oleh Maksum (2015:8) bahwa keefektifan pembelajaran sejarah salah satunya ditentukan oleh komponen buku teks yang dijadikan sebagai sumber belajar.

Darwati (2011:77) menyatakan bahwa pendidik dapat menggunakan buku teks sesuai selera dalam pelaksanaan pembelajaran sejarah, selama buku tersebut diizinkan beredar oleh Departemen 
Pendidikan Nasional (Depdiknas). Penggunaan buku teks Sejarah Indonesia harus memenuhi Standar Nasional Pendidikan. Buku teks Sejarah Indonesia yang digunakan harus mengacu pada KI (Kompetensi Inti), KD (Kompetensi Dasar), dan lingkup materi pada struktur kurikulum. Sedangkan struktur kurikulum harus mengacu pada SKL (Standar Kompetensi Lulusan) dan SI (Standar Isi). Sumaludin (2018) menyatakan bahwa buku teks memiliki kedudukan sebagai acuan dalam pelaksanaan proses pembelajaran karena penyusunannya dilakukan dengan mengacu pada tujuan pendidikan nasional dan standar isi yang telah ditetapkan pemerintah.

Peninjauan ulang mengenai isi dalam buku teks perlu dilakukan. Mengingat di era ini, kebanyakan orang tua hanya berpikir anaknya harus sukses dalam bidang pendidikan berdasarkan angka yang dicapai. Kebanyakan pendidik juga sibuk mengurus angka sehingga lupa tentang karakter yang harus dimiliki anak didiknya dan mengajar hanya sekedar berdasarkan isi buku, tanpa melihat makna yang tersirat dalam buku tersebut. Hal ini membuat pembelajaran mengenai pendidikan karakter seakan-akan pudar melihat banyaknya fenomena kasus penyimpangan akhlak anak dalam dunia pendidikan.

Contoh fenomena kasus dalam dunia pendidikan yaitu video seorang murid yang berani menantang gurunya di Gresik, Jawa Timur dikutip dari News.detik.com (11 Februari 2019). Begitu pula seperti yang dilansir laman News.detik.com (23 Oktober 2019) tentang video seorang guru Penjaskes SMK Muhammadiyah 1 Kota Pasuruan menampar 13 muridnya. Kasus tersebut merupakan sekian dari banyaknya masalah 
karakter yang dimiliki dunia pendidikan, sehingga penerapan PPK di setiap sekolah perlu digalakkan.

Salah satu cara sederhana yang bisa dilakukan pendidik yakni meninjau ulang isi buku teks dan menyampaikan nilai pendidikan karakter yang ada kepada peserta didik. Penyampaian dan penggambaran adanya PPK dalam penulisan buku teks ini dapat diungkap melalui analisis wacana. Darma (2009:49) menjelaskan analisis wacana adalah sebuah usaha untuk menyajikan uraian yang berisi penjelasan sebuah teks yang akan atau sedang dikaji oleh seseorang dengan kecenderungan mempunyai tujuan untuk memperoleh yang diinginkan.

Kajian tersebut dikaji berdasarkan sudut pandang Analisis Wacana Kritis (Critical Discourse Analysis/CDA) yang merupakan salah satu cabang studi bahasa dengan pendekatan multidisipliner. Analisis wacana kritis tidak hanya memahami wacana atau teks semata-mata sebagai obyek studi bahasa, namun teks harus dipahami dalam konteksnya. Wacana dipandang sebagai teks yang selalu terikat pada konteks (Eriyanto, 2011:9). Penelitian ini bermaksud mengungkap tindakan, konteks, dan representasi dari kosa kata dan kalimat dalam buku teks yang terkait dengan Penguatan Pendidikan Karakter (PPK) pada buku teks mata pelajaran sejarah.

Menurut Taufik Abdullah (2005:xviii) sejarah sesungguhnya merupakan sistem wacana, sesuatu yang berbicara tentang sesuatu. Wacana sejarah terikat oleh konteks utamanya yaitu waktu yang menjadi ciri utama ilmu sejarah. Hal ini karena wacana tidak bisa dipahami dalam suatu yang netral maka diperlukan suatu analisis wacana kritis. Dalam hal ini, manfaat wacana dalam pelajaran sejarah berkaitan dengan proses 
membangun kesadaran sejarah dan kesadaran nasional dalam diri peserta didik. Oleh karena itu, perlu adanya analisis wacana kritis dalam memahami suatu pesan yang disampaikan dalam buku teks.

Salah satu kelompok peneliti yang mengembangkan analisis wacana kritis berkaitan dengan tindakan, konteks, dan representasi adalah Roger Fowler, Rober Hodge, Gunther Kress, dan Tony Trew atau yang lebih dikenal dengan nama Roger Fowler dkk. Menurut Eriyanto (2011:133) pendekatan yang digunakan sekelompok peneliti ini adalah critical lingustics yang memandang bahasa sebagai praktik sosial. Dalam analisisnya Roger Fowler dkk lebih menekankan pada penggunaan kosa kata dan tata bahasa yang membawa makna tertentu.

Kajian ini menggunakan kerangka analisis model Roger Fowler dkk yang terdiri dari dua hal penting. Pertama, pada level kata yang berkaitan dengan peristiwa yang akan dibahasakan. Kata-kata yang muncul tidak hanya penanda atau identitas tetapi juga dihubungkan dengan makna yang ingin disampaikan penulis pada pembaca. Kedua, pada level susunan kata atau kalimat yang dimengerti dan dipahami tidak hanya sebagai persoalan teknis kebahasaan tetapi juga praktik bahasa yang memunculkan nilai tertentu (Eriyanto, 2011:164-165).

Penelitian tentang analisis wacana dalam buku teks yang relevan dengan penelitian ini diantaranya kajian milik Utami (2012) yang membahas tentang mengenai praktik wacana dalam buku teks yang dipengaruhi oleh kebijakan politik pendidikan pemerintah. Adapula Agisti Maulidya Briliani (2016) yang meneliti tentang representasi perempuan dalam buku teks Sejarah Indonesia, sedangkan Zafriadi (2017) meneliti tokoh Minangkabau yang direpresentasikan 
sebagai tokoh-tokoh nasionalis dengan kontribusi paling signifikan pada masa penjajahan Belanda. Selanjutnya ada Mardikarini dan Suwarjo (2016) yang menganalisis muatan nilai-nilai karakter buku teks pegangan guru dan siswa.

Berbagai penelitian tersebut belum membahas secara spesifik tentang Penguatan Pendidikan Karakter (PPK) yang ada dalam buku teks Sejarah Indonesia. Pengimplementasian PPK dalam dunia pendidikan telah diatur dalam Peraturan Presiden No 87 Tahun 2017 tentang PPK dan Permendikbud No 20 Tahun 2018 tentang PPK dalam Satuan Pendidikan Formal. Oleh karena itu, penting melihat isi muatan nilai-nilai PPK dalam materi buku teks Sejarah Indonesia yang bisa diungkap dengan analisis wacana kritis.

\section{METODE}

Penelitian ini menggunakan pendekatan kualitatif jenis analisis wacana kritis model Roger Fowler dkk. Kosa kata dan tata kalimat dalam model ini digunakan untuk mengungkap nilai karakter utama PPK yang ada dalam buku teks Sejarah Indonesia. Sumber data utama yang digunakan yaitu buku teks Sejarah Indonesia kurikulum 2013 edisi revisi 2017 kelas X, XI, dan edisi revisi 2018 kelas XII yang diterbitkan oleh Kementerian Pendidikan dan Kebudayaan Republik Indonesia dan bisa diunduh di laman http://puskurbuk.kemendikbud.go.id. Teknik pengumpulan data dilakukan dengan cara dokumentasi. Analisis dalam penelitian ini mengikuti teknik analisis wacana kritis yang dikembangkan oleh Roger Fowler dkk dalam tulisan Eriyanto (2011) menekankan pada suatu realitas yang dibahasakan. Realitas itu menggambarkan peristiwa 
atau aktor-aktor yang melakukan tindakan dituliskan dalam teks melalui bahasa, sebab teks merupakan suatu produk bahasa. Ada dua tingkat level dalam model analisis Roger Fowler dkk. Tingkat level mikro terdiri dari susunan kata dan kalimat yang terdapat dalam teks, sedangkan level makro dikaitkan dengan buku-buku sejarah dan nilai pendidikan karakter yang terkait. Validitas data dilakukan seperti Ibnu Hamad (dalam Utami, 2012) dengan cara holistik (mengaitkan teks dengan konteks.), historical situatedness (menempatkan yang diteliti dalam konteks historical situatedness yang melingkupinya), dan teori (terkait dengan intepretasi dan eksplanasi). Pengecekan data dilakukan secara berulang untuk menghindari kesalahan dan benar-benar mendapatkan hasil yang kebenarannya bisa dipastikan lalu diuraikan dalam bentuk analisis secara deskriptif.

\section{HASIL DAN PEMBAHASAN}

\section{Kecenderungan Tema Penguatan Pendidikan Karakter yang Muncul} dalam Buku Teks Sejarah Indonesia

Buku teks yang digunakan dalam analisis penelitian ini adalah sejarah Indonesia Kurikulum 2013 edisi revisi 2017 terbitan Kementerian Pendidikan dan Kebudayaan Republik Indonesia kelas X, XI, dan edisi 2018 untuk XII yang dapat diunduh di laman http://puskurbuk.kemendikbud.go.id. Kajian analisis buku teks ini berpusat pada nilai-nilai PPK yakni nasionalisme, kemandirian, religius, integritas, dan gotong royong.

Analisis buku teks ini dilakukan berdasarkan per subbab. Hal ini disebabkan tidak semua subbab mengandung nilai-nilai utama PPK. Adapun rincian penulis setiap buku yang dianalisis adalah sebagai berikut: (1) kelas X Kurikulum 2013 edisi revisi 2017, ditulis oleh Restu 
Gunawan, Amurwani Dwi Lestariningsih, Sardiman AM; (2) kelas XI Kurikulum 2013 edisi revisi 2017, ditulis oleh Sardiman AM dan Amurwani Dwi Lestariningsih; serta (3) kelas XII Kurikulum 2013 edisi revisi 2018, ditulis oleh Abdurakhman, Arif Pradono, Linda Sunarti, dan Susanto Zuhdi.

Berdasarkan penelitian analisis wacana kritis pada buku teks tersebut didapatkan hasil seperti tergambar pada tabel berikut.

Tabel 1. Rekapitulasi PPK dalam Buku Teks Sejarah Indonesia SMA Kurikulum 2013

\begin{tabular}{|c|c|c|c|c|c|c|}
\hline \multirow{2}{*}{$\begin{array}{c}\text { Buku Teks } \\
\text { Kelas }\end{array}$} & \multicolumn{5}{|c|}{ Karakter } & \multirow{2}{*}{$\begin{array}{l}\text { Jumlah } \\
\text { Karakter }\end{array}$} \\
\hline & Nasionalisme & Kemandirian & Religius & Integritas & $\begin{array}{l}\text { Gotong } \\
\text { Royong }\end{array}$ & \\
\hline$X$ & 7 & 8 & 8 & 6 & 11 & 40 \\
\hline XI Semester 1 & 22 & 3 & - & 5 & 3 & 33 \\
\hline XI Semester 2 & 17 & 1 & 1 & 4 & 10 & 33 \\
\hline XII & 12 & 3 & - & 4 & 10 & 29 \\
\hline $\begin{array}{c}\text { Jumlah } \\
\text { Karakter }\end{array}$ & 58 & 15 & 9 & 19 & 34 & 135 \\
\hline
\end{tabular}

Berdasarkan data pada tabel tersebut, dapat diketahui bahwa penyebaran nilai PPK yang paling rata ada pada buku teks Sejarah Indonesia kelas X edisi revisi 2017 diikuti dengan kelas XI semester 2. Kedua buku tersebut memiliki nilai utama PPK yang lengkap bila dibandingkan dengann kedua buku lainnya.

Merata dan tidaknya penyebaran nilai PPK tergantung pada materi yang disajikan dalam buku teks Sejarah Indonesia. Selain itu, tidak adanya satu nilai karakter bisa disebabkan oleh penulis yang hanya memaparkan data dan fakta saja sehingga tidak menyisipkan peristiwa, kisah, atau gambar yang menyiratkan nilai PPK. Berikut ini, gambar 1 yang menerangkan lebih lanjut. 


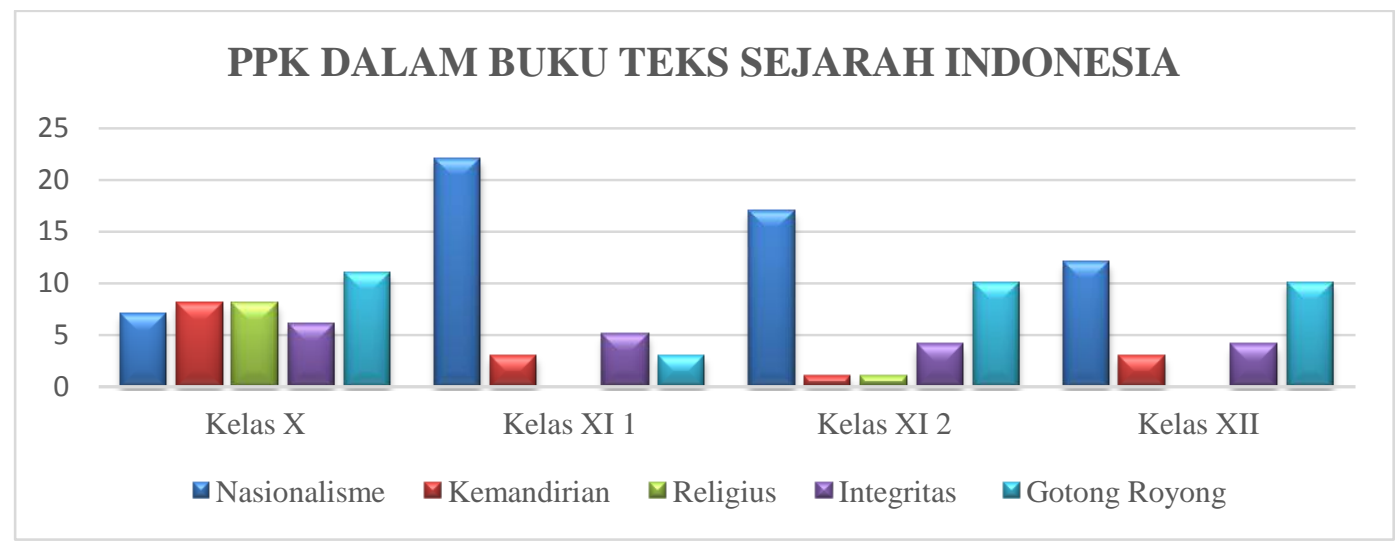

Gambar 1. Penyebaran PPK dalam Setiap Buku Teks Sejarah Indonesia SMA Kurikulum 2013

Urutan nilai PPK berdasarkan frekuensi kemunculan secara keseluruhan buku teks Sejarah Indonesia yaitu nasionalisme, gotong royong, integritas, kemandirian dan religius. Berdasarkan data tabel tersebut, untuk keterangan lebih jelas bisa diketahui jumlah perbandingan setiap karakter yang muncul berdasarkan prosentase seperti gambar 2 di berikut ini.

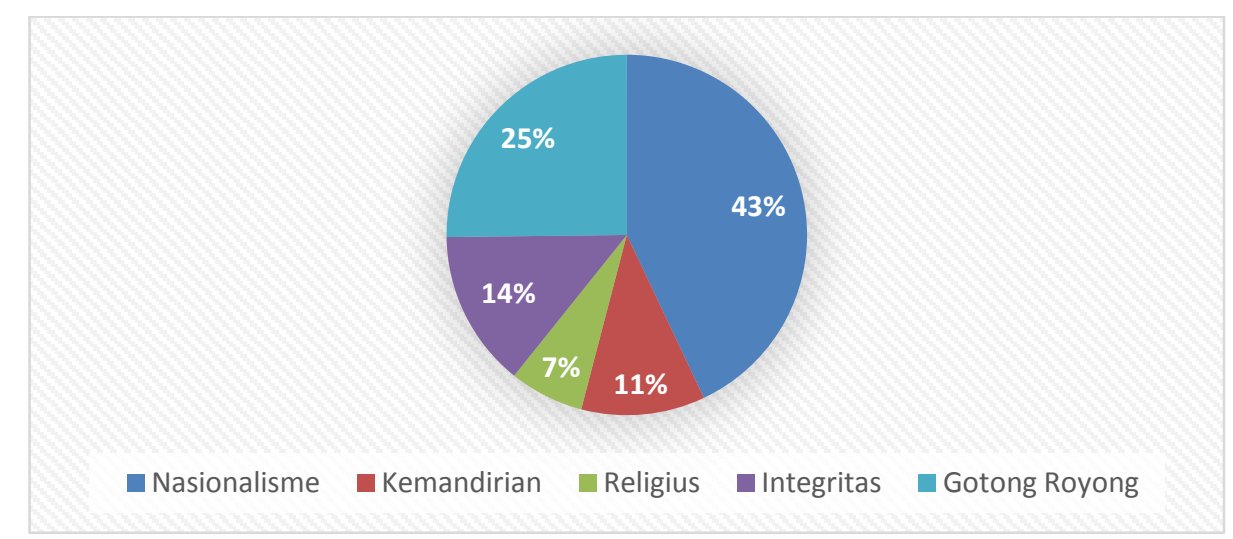

Gambar 2. Prosentase PPK dalam Keseluruhan Buku Teks Sejarah Indonesia SMA Kurikulum 2013

Berdasarkan paparan data hasil analisis model Roger Fowler dkk yang telah dituliskan pada gambar 2 di atas, bisa dikatakankan bahwa nasionalisme merupakan nilai PPK yang sering muncul secara keseluruhan dalam buku teks Sejarah Indonesia kurikulum 2013 Sekolah 
Menengah Atas (SMA). Wacana nasionalisme sangat dominan dalam penulisan buku teks yang berguna untuk pembentukan karakter berbangsa dan bernegara.

Nasionalisme merupakan cara berpikir, bersikap, dan berbuat yang menunjukkan kesetiaan, kepedulian, dan penghargaan yang tinggi terhadap bahasa, lingkungan fisik, sosial, budaya, ekonomi, dan politik bangsa, menempatkan kepentingan bangsa dan negara di atas kepentingan diri dan kelompoknya (Kemdikbud, 2018). Karakter ini menjadi paling dominan dan sering muncul dalam penulisan buku teks. Hal ini dapat dipahami karena berdasarkan materi yang disajikan dalam buku teks terkait dengan perjuangan bangsa Indonesia dalam memperolah kemerdekaan. Nasionalisme yang terdapat dalam buku teks kelas X, XI semester 1 dan 2, serta kelas XII memiliki konteks yang berbeda.

Nasionalisme yang dimaksud dalam buku teks $X$ adalah berkaitan dengan rasa solidaritas. Seperti yang diungkapkan oleh Masroer (2017) yang menjelaskan struktur sosial Nusantara yang dikepalai seorang kepala suku atau raja memiliki pengaruh yang sangat sentral bagi masyarakat sekitarnya. Kepala suku lahir dari ikatan sosial kekerabatan yang menjadi simbol pengikat dan pengembang solidaritas. Sehingga nasionalisme dalam materi yang dinarasikan dalam buku teks kelas $X$ dikaitkan dengan solidaritas kekerabatan.

Pada buku kelas XI semester 1 dan 2, nasionalisme dikaitkan dengan perasaan senasib dan seperjuangan saat melawan penjajahan bangsa Barat. Di Indonesia konsep nasionalisme sudah ada sejak Kerajaan Majapahit yang dikobarkan oleh Patih Gajah Mada dengan istilah 
"Sumpah Palapa" yang bertujuan untuk menyatukan wilayah Nusantara (Alfaqi, 2016). Selanjutnya baru tahun 1902 dengan berdirinya organisasi Budi Utomo sebagai tonggak awal nasionalisme yang mendapat pengaruh dari Barat dan benar-benar terlihat sejak Sumpah Pemuda tahun 1928.

Lahirnya paham nasionalisme sekitar abad ke 20 di Indonesia, menjadi titik awal perubahan sosial bangsa dan dalam buku teks kelas XII banyak kosa kata dan kalimat yang mencerminkan nilai nasionalisme. Hal ini ditunjukkan pada masa kepemimpinan di Indonesia saat jatuh bangun kabinet dan pergantian masa kepemimpinan. Namun, Negara Kesatuan Republik Indonesia tetap berdirinya hingga saat ini.

Berbeda dengan nasionalisme yang paling sering muncul dari keseluruhan buku teks, nilai religius adalah yang paling sedikit muncul. Hal ini menunjukkan bahwa penulisan buku teks sudah semakin ilmiah, tidak lagi bermuara pada tahayul dan mitos yang beredar di masyarakat.

Karakter religius dalam Kemdikbud (2018) yang menggambarkan tentang sikap cinta damai, toleransi, dan rasa persaudaraan yang tinggi dijelaskan secara rasional dan kritis. Meskipun dalam buku teks kelas X, terutama mengenai materi kerajaan masih terdapat tata bahasa yang bersifat irrasional. Namun, masih bisa dijelaskan secara ilmiah terkait dengan konteksnya.

Berkenaan dengan nilai gotong royong. Materi dari buku teks kelas X hingga kelas XII, mencerminkan tindakan dan konteks nilai gotong royong. Nilai gotong royong dijelaskan memiliki arti yang sama yakni kerja sama, tolong menolong, dan musyawarah mufakat. Gotong royong menjadi budaya masyarakat di dunia sejak zaman manusia purba hingga sekarang. Tidak ada manusia yang bisa bertahan hidup sendiri. Sehingga 
berdasarkan analisis penyebaran nilai gotong royong setiap buku teks Sejarah Indonesia digambarkan secara merata.

Karakter kemandirian dalam buku teks kelas X hingga XII memiliki arti yang sama. Seperti yang dikemukakan Kemdikbud (2018) nilai karakter mandiri merupakan sikap dan perilaku tidak bergantung pada orang lain dan mempergunakan segala tenaga, pikiran, waktu untuk merealisasikan harapan, mimpi, dan cita-cita.

Kemdikbud (2018) menyatakan bahwa integritas adalah sikap tanggung jawab sebagai warga negara, aktif terlibat dalam kehidupan sosial, melalui konsistensi tindakan dan perkataan yang berdasarkan kebenaran. Keteladanan mengenai karakter ini telah ada sejak zaman kerajaan yang tercermin dari sikap seorang raja yang menjadi contoh bagi rakyatnya. Hingga saat ini, karakter ini sangat diperlukan untuk membangun karakter bangsa yang unggul.

Melalui adanya nilai PPK ini, peserta didik diharapkan setidaknya mampu memahami makna yang tersirat dari setiap kisah, peristiwa, dan tragedi yang tertulis dalam materi buku teks Sejarah Indonesia. Sedangkan pendidik diharapkan tidak hanya menyampaikan sekedar materi fakta saja tetapi juga perlu menginternalisasikan nilai penguatan pendidikan karakter itu dalam diri peserta didiknya. Baik melalui motivasi ataupun contoh langsung yang kontekstual dengan materi yang diajarkan.

\section{Keterkaitan Penguatan Pendidikan Karakter dalam Buku Teks Sejarah Indonesia dengan Kebijakan Kurikulum 2013}

Setiap penulisan buku teks tidak lepas dari subjektivitas penulis dan kebijakan atau aturan yang ada, termasuk juga dalam penulisan buku 
teks Sejarah Indonesia kurikulum 2013 Sekolah Menengah Atas (SMA). Ada berbagai aturan pemerintah yang mengatur penulisan tersebut sehingga harus sesuai Badan Standar Nasional Pendidikan (BNSP). Dalam penulisan buku teks Sejarah Indonesia tentu terikat dengan kebijakan pemerintah berupa kurikulum sebagai rambu-rambu yang harus ditaati.

Penulisan buku teks juga tidak lepas dari wacana kebijakan pemerintah dalam bidang pendidikan. Kemdikbud (2019) menyatakan bahwa salah satu kebijakan pemerintah dibidang pendidikan adalah mewujudkan program Nawacita yang dicanangkan oleh Presiden Joko Widodo - Jusuf Kalla dalam sistem pendidikan nasional yang terintegrasikan dengan Gerakan Nasional Revolusi Mental (GNRM). Kebijakan ini diatur dalam Pepres No. 87 Tahun 2017 tentang Penguatan Pendidikan Karakter (PPK).

Kurikulum dan PPK adalah bentuk kebijakan pemerintah, dimana kurikulum yang berlaku saat ini adalah kurikulum 2013. Kurikulum ini mengalami beberapa kali revisi seiring dengan perkembangan kebutuhan, edisi terakhir adalah Kurikulum 2013 Revisi 2016. Revisi ini sedikit banyak berdampak pada materi yang tercantum dalam buku teks, terutama pada pencapaian kompetensi dasar yang ditetapkan. Hal ini dilakukan sebagai jawaban atas tantangan dan perubahan zaman.

Penerapan kurikulum 2013 intinya terletak pada usaha untuk menyederhanakan sajian materi secara dan tematik-integratif dengan tujuan untuk menciptakan generasi yang siap menghadapi tantangan masa depan (Wahyuni, 2015). Oleh karena itu, kurikulum 2013 disusun untuk mengantisipasi perkembangan zaman dan disesuaikan dengan kebutuhan masyarakat. Ciri dari kurikulum 2013 terletak pada 
pendekatan saintifik dan penilaian autentik. Namun semenjak tahun 2016 terdapat perubahan atau penyempuranaan pada beberapa aspek yang disesuaikan dengan tuntutan kebutuhan.

Secara keseluruhan ada empat point penting dalam kurikulum 2013 edisi revisi meliputi: (a) penyederhanaan aspek penilaian; (b) proses berpikir peserta didik tidak dibatasi; (c) penerapan teori 5M (mengingat, memahami, menerapkan, menganalisis, dan mencipta) disesuai dengan metode pembelajaran; serta (d) struktur matapelajaran dan lama belajar di sekolah tidak diubah. Oleh karena itu, penulisan buku teks Sejarah Indonesia juga harus mengacu pada kurikulum 2013 edisi revisi.

Adapun wacana kebijakan pemerintah selanjutnya yang ada dalam buku teks yang mengacu pada kurikulum 2013 adalah Penguatan Pendidikan Karakter (PPK). Sebagaimana yang dijelaskan dalam Perpres No 87 Tahun 2017 tentang PPK pada pasal 3 bahwa PPK dilaksanakan dengan menerapkan nilai-nilai Pancasila dalam pendidikan karakter terutama meliputi nilai-nilai religius, jujur, toleran, disiplin, bekerja keras, kreatif, mandiri, demokratis, rasa ingin tahu, semangat kebangsaan, cinta tanah air, menghargai prestasi, komunikatif, cinta damai, gemar membaca, peduli lingkungan, peduli sosial, dan bertanggungjawab.

Penerapan nilai-nilai Pancasila dalam pendidikan karakter tersebut nantinya diintegrasikan dalam penulisan buku teks sesuai dengan prinsip pengembangan dan implementasi PPK secara terintegrasi. Kemdikbud (2018) menjelaskan bahwa gerakan PPK dikembangkan dan dilaksanakan dengan memadukan, menghubungkan, dan mengutuhkan berbagai elemen pendidikan. Bedasarkan hal tersebut, buku teks merupakan salah satu elemen pendidikan sebagai sumber belajar bisa menjembatani 
pelaksanaan PPK. Hal ini disebabkan dalam materi buku teks Sejarah Indonesia terdapat kisah, cerita, dan tragedi yang mengandung nilai-nilai pendidikan karakter.

Isu mengenai kebijakan adanya PPK bukanlah hal yang baru, karena sejak tahun 2010 sudah menjadi gerakan nasional yang diwacanakan oleh pemerintah untuk mengatasi kemerosotan moral bangsa Indonesia. Peraturan Presiden Nomor 87 Tahun 2017 menjelaskan tentang Pengguatan Pendidikan Karakter yang dalam pasal 1 menyebukan bahwa.

Penguatan Pendidikan Karakter yang selanjutnya disingkat PPK adalah gerakan pendidikan di bawah tanggung jawab satuan pendidikan untuk memperkuat karakter peserta didik melalui harmonisais olah hati, olah rasa, olah pikir, dan olah raga dengan pelibatan dan kerjasama antara satuan pendidikan, keluarga, dan masyarakat sebagai bagaian dari Gerakan Nasional Revolusi Mental (GNRM).

Gerakan PPK dapat diartikan sebagai perwujudan Gerakan Nasional Revolusi Mental sekaligus bagian integral dari program Nawacita Presiden Joko Widodo - Jusuf Kalla pada tahun 2014. Gerakan ini bertujuan untuk memposisikan pendidikan karakter sebagai dimensi terdalam atau inti pendidikan nasional sehingga pendidikan karakter menjadi poros pelaksanaan pendidikan dasar dan menengah. Untuk mewujudkan hal tersebut gerakan PPK perlu mengintegrasikan, memperdalam, memperluas, dan sekaligus menyelaraskan berbagai program dan kegiatan pendidikan karakter yang sudah dilaksanakan sebelumnya (Kemdikbud, 2016).

PPK menjadi sebuah rancangan pemerintah dalam mempersiapkan genarasi emas tahun 2045. Oleh karena itu, pemerintah merancang pembenahan moral generasi muda bangsa Indonesia. Salah satunya 
melalui penginternalisasian PPK dalam buku teks yang diajarkan di sekolah, tidak terkecuali buku teks Sejarah Indonesia. Buku teks Sejarah Indonesia memiliki peran penting untuk mencanangkan internalisasi PPK yang diinginkan pemerintah. Karena melalui buku teks ini, diharapkan tujuan PPK dapat terwujud sesuai Peraturan Presiden No 87 Tahun 2017 pasal 2 yang salah satunya untuk memberikan bekal kepada peserta didik yang merupakan generasi emas Indonesia tahun 2045 dengan jiwa Pancasila dan pendidikan karakter untuk menghadapi dinamika perubahan di masa mendatang.

Persiapan pemerintah dalam membenahi moral generasi muda tidak hanya menciptakan produk PPK. Dalam dunia pendidikan, pemerintah juga turut andil dalam kebijakan yang terdapat dalam kurikulum. Kurikulum adalah produk pemerintah dalam politik sosial budaya pendidikan. Kurikulum yang dilaksanakan oleh setiap satuan pendidikan sudah diatur oleh pemerintah. Oleh karena itu, dapat dikatakan bahwa buku teks yang digunakan tingkat sekolah dasar hingga menengah atas, proses produksi hingga distribusinya dikontrol oleh pemerintah.

Pengontrolan produksi buku teks ini berkaitan dengan konteks yang ada di dalamnya, seperti materi Sejarah Indonesia harus sesuai dengan kurikulum yang berlaku. Materi mengenai Sejarah Nasional yang terdapat dalam buku teks Sejarah Indonesia kurikulum 2013 dianggap harus memiliki pembelajaran kolektif mengenai pembentukan jati diri bangsa dan pemersatu berdasarkan pengalaman bangsa. Oleh sebab itu, secara teknis konseptual buku teks sejarah Indonesia harus mengikuti Garis-garis Besar Program Pengajaran (GBPP) menurut kurikulum dan 
harus memenuhi kelayakan isi, penyajian, kebahasaan, serta kegrafikan bersadarkan Badan Standar Nasional Pendidikan (BNSP).

Bambang Suryadi (2017:5) menjelaskan bahwa inti antara implikasi Perpres PPK terhadap Standar Nasional Pendidikan (SNP) dan kurikulum. Dalam penerapan PPK perlu adanya penguatan substansi keilmuan, karakter, dan budaya. Penguatan substansi isi keilmuan dapat dilihat dari rumusan SKL dan SI pada dokumen SNP dan rumusan KI dan KD pada dokumen kurikulum. Penguatan ini dapat dilakukan melalui kegiatan kurikuler, kokurikuler, dan ekstrakulikuler. Sedangkan penguatan budaya menjadi tanggung jawab tiga institusi pendidikan yakni formal, nonformal, dan informal.

Berdasarkan penjelasan tersebut, dapat disimpulkan bahwa kunci utama penanaman karakter tidak terlepas dari teladan yang harus muncul pada diri seorang pendidik. Hal ini disebabkan karena penanaman karakter tidak dapat dilakukan hanya dengan proses pengajaran, tetapi juga keteladanan yang nyata. Keterkaitan antara PPK dalam buku teks Sejarah Indonesia dengan tujuan kebijakan pemerintah bisa terlaksana jika ada kesadaran dari setiap pelaku dalam dunia pendidikan, terutama pendidik dan peserta didik.

\section{KESIMPULAN}

Buku teks Sejarah Indonesia kurikulum 2013 edisi revisi kelas X, XI, dan edisi revisi 2018 kebanyakan cenderung memiliki karakter nasionalisme. Hal ini karena untuk mengarahkan pada sebuah konsep mengenai jati diri kebangsaan yang berfungsi dalam penetapan identitas individu diantara masyarakat dunia. Bertolak belakang pada nilai religius yang paling sedikit muncul. Hal ini disebabkan oleh penulisan yang 
sudah kritis dan mengikuti pemikiran ilmiah, sehingga tidak bersifat mitos. Adanya PPK dalam buku teks Sejarah Indonesia tidak lepas dari kebijakan pemerintah. Di samping itu, pemerintah juga membuat kebijakan kurikulum yang mengatur tentang materi dalam buku teks, yang mana buku teks tersebut harus memenuhi syarat kelayakan BSNP. Oleh karena itu, penanaman nilai karakter salah satunya bisa melalui buku teks dengan syarat adanya keteladanan dari seorang pendidik yang mengajar.

\section{DAFTAR PUSTAKA}

Abullah, T. 2005. "Kata Pengantar" dalam Sartono Kartodirjo. Sejak Indisch sampai Indonesia. Jakarta: Penerbit Buku Kompas.

Alfaqi, M.Z. 2016. Melihat Sejarah Nasionalisme Indonesia Untuk Memupuk Sikap Kebangsaan Generasi Muda. Jurnal Civics, 13(2):209-216.

Briliani, A.M. 2016. Analisi Wacana Kritis: Representasi Perempuan dalam Buku Teks Sejarah Indonesia Berdasarkan Kurikulum 2013 Kelas X, XI, XII Sekolah Menengah Atas. Skripsi tidak diterbitkan. Malang: Fakultas Ilmu Sosial Universitas Negeri Malang.

Darma, Y.A. 2009. Analisis Wacana Kritis. Bandung: Yrama Widya.

Eriyanto. 2011. Analisis Wacana: Pengantar Analisis Teks Media. Yogyakarta: LKIS.

Kemdikbud. 2016. Panduan Penilaian Oleh Pendidik dan Satuan Pendidikan Untuk Sekolah Menengah Atas. Jakarta: Kementerian Pendidikan dan Kebudayaan.

Kemdikbud. 2018. Konsep dan Pedoman Penguatan Pendidikan Karakter. Jakarta: Kementerian Pendidikan dan Kebudayaan Republik Indonesia.

Kemdikbud. 2019. Penguatan Pendidikan Karakter: Menumbuhkan Generasi Cerdas dan Berkarakter, (Online). Dari https://cerdasberkarakter.kemdik bud.go.id/?page_id=132, diakses 2 April 2019.

Maksum. 2015. Intepretasi Sejarah sebagai Peristiwa dan Masalah Pendidikan. At- Tarats, 9(2). 
Mardikarini, S \& Suwarjo. 2016. Analisis Muatan Nilai-nilai Karakter Pada Buku Teks Kurikulum 2013 Pegangan Guru dan Pegangan Siswa. Jurnal Pendidikan Karakter, 6(2):261-274.

Marzuki. 2012. Pengintegrasian Pendidikan Karakter dalam Pembelajaran di Sekolah. Jurnal Pendidikan Karakter, (2):33-44.

Masroer. 2017. Gagasan Nasionalisme Indonesia Sebagai Negara Bangsa Dan Relevansi Dengan Konstitusi Indonesia. Sosiologi Agama: Jurnal Ilmiah Sosiologi Agama dan Perubahan Sosial, 11(2):229-238.

Mulyasa, E. 2011. Menjadi Guru Profesional. Bandung: PT Remaja Rosdakarya.

News.detik.com. 11 Februari 2019. Fenomena Murid Tantang Guru, Apakah Pendidikan Keras Jadi Solusi?. Dari https://news.detik.com/berita/d4423678/fenomena-murid-tantang-guru-apakah-pendidikankeras-jadi-solusi, diakses 10 Februari 2020.

News.detik.com. 23 Oktober 2019. Cerita Lengkap Kasus Guru Tampar 13 Murid di Kota Pasuruan. Dari https://news.detik.com/berita-jawatimur/d-4756436/cerita-lengkap-kasus-guru-tampar-13-murid-dikota-pasuruan-yang-viral, diakses 10 Februari 2020.

Pemendikbud Nomor 20 Tahun 2018 Tentang Penguatan Pendidikan Karakter dalam Satuan Formal Pendidikan. Jakarta: Depdiknas.

Pemendikbud Nomor 36 Tahun 2018 Tentang Kurikulum 2013 Sekolah Menengah Atas/Madarasah Aliyah. Jakarta: Depdiknas.

Peraturan Presiden Nomor 87 Tahun 2017 Tentang Penguatan Pendidikan Karakter

Sumaludin, M.M. 2018. Identitas Nasional dalam Buku Teks Pelajaran Sejarah SMA. HISTORIA: Jurnal Pendidik dan Peneliti Sejarah, 1(2):97-104.

Suryadi, B. 2017. Perpres PPK dan Posisi Standar Nasional Pendidikan dalam Penguatan Pendidikan Karakter. Buletin BNSP, 12(4):3-5.

Tarigan, H.G. 2009. Analisis Buku Teks. Bandung: Angkasa.

Utami, I.W.P. 2014. Wacana Ideologi Negara dalam Buku Sekolah Elektronik (BSE) Sejarah Sekolah Menengah Atas (SMA). Tesis tidak diterbitkan. Surakarta: Universitas Sebelas Maret.

Wahyuni, F. 2015. Kurikulum dari Masa ke Masa. Jurnal Al-Adabiya, 10(2):231-242.

Zafriadi. 2017. Analisis Wacana Kritis: Representasi Tokoh Minangkabau dalam Buku Teks Sejarah Indonesia. Skripsi tidak diterbitkan Malang: Universitas Negeri Malang. 